\title{
BINGKAI MEDIA TERHADAP BERITA KOMUNIKASI PEMERINTAH DI PANDEMI COVID-19
}

\author{
Sukma Alam \\ Program Studi Ilmu Komunikasi FIKOM \\ Universitas Budiluhur \\ Jakarta Selatan \\ Sukma.alam@budiluhur.ac.id
}

\begin{abstract}
One of the successful handling of COVID-19 in one country is the government's ability to communicate with the public. In Indonesia, the issue of government communication is a hot topic discussed not only from the health sector but also contains enormous political and economic problems. The news about government communications in COVID-19 pandemic became the public spotlight. Therefore, government communication is not running optimally and ignores corona virus. This research aims to study to find out the framing of government communication in detik.com, kompas.com and kumparan.com news and to study the highlighting and selection of issues in government communication news in COVID-19 pandemic conducted detik.com, kompas.com and kumparan.com. The method used in this research is Robert M. Entman's framing analysis. The results of this study are finding framing in the news that was raised by detik.com framing government communication as serious, kompas.com framing government communication as a crucial issue and kumparan.com framing government communication issues in political terms. While from the aspect of issue selection, detik.com is more a challenge that is directly related to the community, kompas.com is more about the problem of government communication and kumparan.com Criticism builds and kumparan.com further corners the government.
\end{abstract}

Keywords: FRAMING, GOVERNMENT COMMUNICATION NEWS, COVID-19

\section{PENDAHULUAN}

Komunikasi pemerintah dalam penanganan COVID-19 disoroti berbagai pihak. Situasi tersebut memunculkan ketidakpercayaan publik terhadap pemerintah. Permasalahannya saat bencana tiba, komunikasi pemerintah tidak berjalan maksimal. Sejak munculnya virus corona pada akhir Desember 2019, Indonesia cenderung tidak merespons dan abai terhadap virus tersebut. Sehingga, komunikasi pemerintah menjadi tidak optimal. Selain itu, komunikasi antar kementerian, pemerintah pusat dengan daerah tidak berjalan dengan baik malah hal ini diperlihatkan ke publik. Mengutip tulisan Gun Gun Heryanto di Republika, dalam mengomunikasikan mengenai kebijakan, pemerintah harus lebih jelas, lebih logis dan lebih bisa dipahami masyarakat. Sebab, isu Covid-19 merupakan isu krusial dan proses penyampaian pesan ke publik secara transparan dan terbuka.

Pelaku komunikasi pemerintah seperti presiden, menteri, kepala daerah gagap menanggapi beredarnya isu dalam menangani COVID-19. Cara komunikasi yang dipilih pemerintah bermaksud agar publik tidak panik dan merasa tenang. Namun respons tersebut terkesan 
menganggap remeh malah pernyataan pemerintah bertentangan dengan data dan fakta di lapangan. Selama menghadapi pandemi, pemerintah telah melakukan sejumlah blunder atau kekeliruan. Dikutip voaindonesia.com, Lembaga Penelitian, Pendidikan, Penerangan Ekonomi dan Sosial (LP3ES) mencatat ada 37 pernyataanya blunder dari pemerintah. Beberapa contohnya, Wakil Presiden RI Ma'ruf Amin menyebut virus corona bisa disingkirkan dari Indonesia dengan doa Qunut, Menko Perekonomian Airlangga Hartarto juga mengatakan bahwa virus corona tidak masuk ke Indonesia karena perizinannya susah. Sementara, juru bicara pemerintah untuk penanganan COVID-19, Achmad Yurianto meminta masyarakat miskin tidak menularkan virus corona kepada orang kaya (https://www.voaindonesia.com/a/pemerintah-harus-perbaikikomunikasi-publik-terkait-corona/5364324.html).

Gambar 1

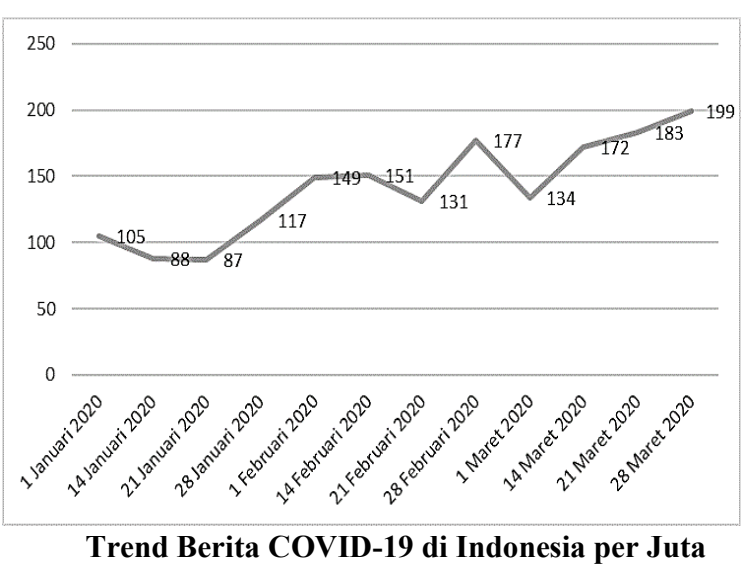

Sumber: https://jksg.umy.ac.id/research-press-release-framing-media-terhadap-kepercayaan-publik-dalamkebijakan-pandemi-covid19-di-indonesia/

Berdasarkan gambar di atas bahwa berita tentang COVID-19 menjadi berita utama yang dikonsumsi khalayak. Dalam research press release yang berjudul "Framing Media Terhadap Kepercayaan Publik dalam Kebijakan Pandemi COVID-19 di Indonesia", ditemukan bahwa hampir semua media arus utama menyoroti tentang COVID-19, seperti kebijakan keputusan untuk mendefinisikan dan mencegah penyebaran virus. Bahkan jumlah pembaca terkait COVID-19 terus meningkat dari Januari hingga Maret 2020.

Persoalan komunikasi pemerintah menjadi isu penting bagi media massa. Bahkan media massa terang-terangan mengkritik pemerintah selama pandemi COVID-19. Upaya media massa melakukan kritik terhadap kondisi pemerintahan, sesungguhnya terkait dengan fungsi media di tengah khalayak yang beragam. Media massa berperan dalam penyebaran informasi yang memberikan manfaat kepada masyarakat (Susanto, 2011).

Pemberitaan media massa mengenai kekritisan terhadap komunikasi pemerintah tampak dalam berita kompas.com pada Senin, 13 April 2020 yang berjudul "Koalisi Masyarakat Sipil Soroti Buruknya Komunikasi Pemerintah Tangani COVID-19". Berita ini intinya 


\section{BINGKAI MEDIA TERHADAP BERITA KOMUNIKASI PEMERINTAH DI PANDEMI}

\section{COVID-19}

mempermasalahkan komunikasi pemerintah yang dianggap tidak siap dalam menangani pandemi COVID-19 seperti meremehkan virus corona, kebijakan yang tidak konsisten, dan komunikasi tidak baik antara pemerintah pusat dengan daerah.

Informasi terkait komunikasi pemerintah, media menunjukan perhatiannya terhadap pemerintah mengenai penanganan COVID-19. Hal tersebut "upaya" media massa menggambarkan objektivitas dalam sebuah berita. Objektivitas ialah fakta yang ada dalam laporan perulah netral dan tidak bias (Syam, 2016:63). Syam menjelaskan, bias yang dimaksud dipengaruhi beberapa faktor seperti faktor manusia (wartawan, redaktur, dan sumber), faktor organisasi (kebijakan organisasi media dan pemilih media), faktor politik (keadaan politik di mana organisasi media itu beroprasi) dan faktor ekonomi (pengiklan). Kondisi saat ini sulit dijumpai berita di media massa yang mengedepankan objektivitas karena dipengaruhi tempat kerja, pergaulan dan latar belakang budaya. Dengan kata lain tidak ada teks media atau berita yang sepenuhnya objektif atau hanya kumpulan fakta yang dijadikan data untuk sebuah siaran, tayangan, dan tulisan (Iskandar \& Lestari, 2016:13). Dalam penelitian yang dilakukan Indah Suryawati (2019), pandangan konstruksionis, berita diibaratkan seperti sebuah drama di mana terjadi pertarungan antara berbagai pihak yang berkaitan dengan sebuah peristiwa. Lebih lanjut, hal itu tertuang dalam editorial atau tajuk rencana, tetapi juga pada pemilihan headline untuk menentukan arah berita itu sendiri.

Komunikasi pemerintah di pandemi COVID-19 sangat menarik dari perspektif berita. Tentu saja sebagai sebuah berita, media mengkonstruksi realitas sosial. Peristiwa yang sama di lapangan, namun media menanyangkan suatu peristiwa yang dianggap penting yang layak dikonsumsi oleh khalayak. Artinya, mana yang bagian harus ditonjolkan dan mana yang dihilangkan. Tak heran bila menonton atau membaca berita seolah peristiwa tersebut nyata dengan sebenarnya. Ada peristiwa yang dimaknai secara berbeda, dengan wawancara dan orang yang berbeda dengan titik perhatian berbeda.

Media hanya melihat satu perspektif tertentu maka realitas yang ditampilkan ke khalayak merupakan realitas yang sudah dikonstruksi oleh media. Media mempunyai kepentingan masingmasing dalam menayangkan peristiwa yang akan diberitakan ke khalayak. Kepentingan media hanya semata ingin mendapatkan aktualitas, selalu memberitakan terdepan dan kepentingan ideologinya serta memenuhi kepentingan ekonomi-politik. Adanya beragam kepentingan inilah media turut mempengaruhi berita yang disampaikan kepada khalayak. Oleh karena itu, fakta yang disampaikan bukan fakta objektif melainkan fakta yang sudah dikonstruksi oleh media. Semua proses pembentukan media (mulai, dari memilih fakta, sumber, pemakaian kata, gambar, sampai penyuntingan) memberi andil bagaimana realitas tersebut hadir di hadapan khalayak ini (Eriyanto, 2012:26).

Melihat penjelasan di atas menjadi menarik perhatian dalam konstruksi media dan menyajikan berita COVID-19 tentang komunikasi pemerintah. Secara ringkas penelitian ini akan menjelaskan konstruksi realitas komunikasi pemerintah oleh tiga media massa yakni detik.com, kompas.com dan kumparan.com melalui analisis framing. Alasan memilih ketiga media tersebut intensif memberitakan komunikasi pemerintah di pandemi. Ketiganya merupakan media nasional

ACTA DIURNA | VOL. 17 NO.1 2021 
berbasis online memiliki jumlah viewers terbanyak dan masuk dalam 10 media online terbesar di Indonesia sampai Juli 2020 (https://www.alexa.com/topsites/countries/ID diakses pada Selasa, 23 Juli 2020).

Tujuan penelitian ini adalah untuk mengetahui pembingkaian (framing) komunikasi pemerintah dalam berita detik.com, kompas.com dan kumparan.com dan untuk mengetahui penonjolan dan seleksi isu dalam berita komunikasi pemerintah di COVID-19 yang dilakukan detik.com, kompas.com dan kumparan.com.

\section{METODE PENELITIAN}

Metode dalam penelitian ini adalah framing Entman. Framing adalah usaha untuk mengetahui bagaimana perspektif yang digunakan oleh wartawan ketika menyeleksi isu dan menulis menjadi berita (Syam, 2016:154). Analisis framing merupakan analisis isi kualitatif, tidak berkaitan dengan hitung-hitungan maupun angka. Karena fokusnya pada teks berita yang menjadi objek penelitian ini. Penelitian kualitatif menekankan sifat realitas yang dibangun secara sosial, hubungan yang intim antara peneliti dengan yang dipelajari dan kendala situasional yang membentuk penyelidikan (Eriyanto, 2013:37).

Paradigma dalam penelitian ini adalah konstruktivisme. Paradigma konstruktivisme melihat bagaimana suatu realitas sosial dikonstruksikan (Syam, 2016:146). Karena itu, fokus dari analisis yang menggunakan paradigma konstruksionis adalah menemukan realitas dikonstruksi dengan cara apa konstruksi itu dibentuk. Guba dan Lincoln menyatakan bahwa sesuatu yang riil sesungguhnya merupakan sebuah konstruksi dalam pikiran para individu (Denzin dan Lincoln, 2009:162).

Metode penelitian yang digunakan adalah analisis framing dengan model Entman melihat framing dalam dua dimensi besar yaitu seleksi isu dan penonjolan aspek. Dalam konsep Entman, framing pada dasarnya merujuk pada definisi, penjelasan, evaluasi dan rekomendasi. Sementara itu, objek penelitian yang akan dianalisis adalah berita detik.com kompas.com dan kumparan.com mengenai isu komunikasi pemerintah. Objek penelitian dipilih sepuluh berita pada periode April 2020 karena diperiode tersebut komunikasi pemerintah sedang disorot media nasional. Berikut berita yang akan dianalisis:

\section{Tabel 1}

Objek Penelitian Detik.com

\begin{tabular}{|c|c|c|c|}
\hline No. & Judul Berita & Media & Waktu Terbit \\
\hline 1. & $\begin{array}{c}\text { Catatan Gerindra Soal Penanganan } \\
\text { Corona, Komunikasi Pemerintah } \\
\text { Kurang Efektif }\end{array}$ & Detik.com & Rabu, 1 April 2020 \\
\hline 2. & $\begin{array}{c}\text { Pemerintah Bolehkan Mudik di } \\
\text { Tengah Corona, Ekonom: Kacau! }\end{array}$ & Detik.com & Minggu, 5 April 2020 \\
\hline
\end{tabular}

ACTA DIURNA | VOL. 17 NO.1 2021 


\section{BINGKAI MEDIA TERHADAP BERITA KOMUNIKASI PEMERINTAH DI PANDEMI}

\section{COVID-19}

\begin{tabular}{|c|c|c|c|}
\hline 3. & $\begin{array}{c}\text { LP3ES: Ada 37 Pernyataan Blunder } \\
\text { Pemerintah Terkait Penanganan } \\
\text { Corona }\end{array}$ & Detik.com & Senin, 6 April 2020 \\
\hline
\end{tabular}

\section{Sumber: Detik.com}

Tabel 2

Objek Penelitian Kompas.com

\begin{tabular}{|c|c|c|c|}
\hline No. & Judul Berita & Media & Waktu Terbit \\
\hline 1. & $\begin{array}{c}\text { Komunikasi Pemerintah soal } \\
\text { COVID-19 Dikritik, Jokowi } \\
\text { Disarankan Tunjuk Jubir yang Lebih } \\
\text { Ulung }\end{array}$ & Kompas.com & Senin, 6 April 2020 \\
\hline 2. & $\begin{array}{c}\text { Koalisi Masyarakat Sipil Soroti } \\
\text { Buruknya Komunikasi Pemerintah } \\
\text { Tangani COVID-19 }\end{array}$ & Kompas.com & Senin, 13 April 2020 \\
\hline 3. & $\begin{array}{l}\text { Polemik Permenhub soal Ojek } \\
\text { Online, PPP Nilai Koordinasi } \\
\text { Pemerintah Lemah }\end{array}$ & Kompas.com & Senin, 13 April 2020 \\
\hline 4. & $\begin{array}{l}\text { COVID-19 Bukan Cuma Isu } \\
\text { Kesehatan, Pemerintah Diminta } \\
\text { Perbaiki Sinergi Informasi }\end{array}$ & Kompas.com & Jumat, 17 April 2020 \\
\hline
\end{tabular}

\section{Sumber: Kompas.com}

Tabel 3

Objek Penelitian Kumparan.com

\begin{tabular}{|c|c|c|c|}
\hline No. & Judul Berita & Media & Waktu Terbit \\
\hline 1. & $\begin{array}{c}\text { Politikus PKS Kritik Istana yang } \\
\text { Tak Satu Suara Soal Staf KSP } \\
\text { Positif Corona }\end{array}$ & Kumparan.com & Minggu, 5 April 2020 \\
\hline 2. & $\begin{array}{c}\text { Komisi 1 DPR Komentari Jubir } \\
\text { Penanganan COVID-19: Jangan } \\
\text { Hanya Jumlah Korban }\end{array}$ & Kumparan.com & Selasa, 7 April 2020 \\
\hline 3. & $\begin{array}{c}\text { Komisi III Kritik Koordinasi Luhut- } \\
\text { Terawan soal Ojol: Warga Bisa Tak } \\
\text { Ikuti PSBB }\end{array}$ & Kumparan.com & Senin, 13 April 2020 \\
\hline
\end{tabular}

Sumber: Kumparan.com 
HASIL DAN PEMBAHASAN

Pembingkaian Detik.com, Kompas.com dan Kumparan.com

Pada pemberitaan media online detik.com, kompas.com dan kumparan.com periode April 2020 menunjukan perbedaan pembingkaian terkait berita komunikasi pemerintah di COVID19. Berikut pembingkaian media dalam bentuk table di bawah ini:

\section{Tabel 3}

\section{Pembingkaian Detik.com, Kompas.com dan Kumparan.com}

\begin{tabular}{|c|c|c|c|}
\hline Analisa Framing & Detik.com & Kompas.com & Kumparan.com \\
\hline $\begin{array}{c}\text { Problem } \\
\text { Identification } \\
\text { (peristiwa dilihat } \\
\text { sebagai apa) }\end{array}$ & $\begin{array}{c}\text { Detik.com meletakan } \\
\text { komunikasi pemerintah } \\
\text { pada permasalahan serius. } \\
\text { Informasi yang beredar di } \\
\text { publik harus ditanggapi } \\
\text { secara tanggap, cepat dan } \\
\text { proposional. }\end{array}$ & $\begin{array}{c}\text { Kompas.com } \\
\text { mendefinisikan isu } \\
\text { komunikasi pemerintah } \\
\text { sebagai isu krusial. } \\
\text { Maka frame } \\
\text { kompas.com, } \\
\text { cenderung mengkritik } \\
\text { membangun. }\end{array}$ & $\begin{array}{c}\text { Kumparan.com } \\
\text { mendefinisikan isu } \\
\text { komunikasi pemerintah } \\
\text { dari aspek politik karena } \\
\text { koordinasi antar } \\
\text { pemerintah kurang } \\
\text { maksimal. }\end{array}$ \\
\hline $\begin{array}{l}\text { Causal interpretation } \\
\text { (penyebab masalah) }\end{array}$ & $\begin{array}{l}\text { Pertama, kurang efektif } \\
\text { dalam membangun } \\
\text { komunikasi. Kedua, } \\
\text { kebijakan pemerintah } \\
\text { pusat yang tidak konsisten }\end{array}$ & $\begin{array}{c}\text { Kompas.com } \\
\text { menganggap } \\
\text { penyebabnya adalah } \\
\text { permasalahan juru } \\
\text { bicara dan koordinasi. }\end{array}$ & $\begin{array}{l}\text { Penyebab komunikasi } \\
\text { pemerintah pada berita ini } \\
\text { adalah pemerintah tidak } \\
\text { tegas, juru bicara dan } \\
\text { koordinasi antar } \\
\text { kementerian. }\end{array}$ \\
\hline $\begin{array}{l}\text { Moral Evaluation } \\
\text { (penilaian atas } \\
\text { penyebab masalah) }\end{array}$ & $\begin{array}{l}\text { Komunikasi menjadi } \\
\text { penting dalam } \\
\text { membangun kepercayaan } \\
\text { publik atas kemampuan } \\
\text { pemerintah menangani } \\
\text { virus corona. }\end{array}$ & $\begin{array}{l}\text { Kompas.com menilai } \\
\text { permasalahan yakni } \\
\text { pemerintah perlu } \\
\text { membangun } \\
\text { kepercayan publik } \\
\text { dengan komunikasi } \\
\text { publik. }\end{array}$ & $\begin{array}{l}\text { Kumparan.com menilai } \\
\text { bahwa pemerintah } \\
\text { mengambil langkah } \\
\text { kebijakan yang strategis } \\
\text { dan proaktif agar } \\
\text { masyarakat tidak bingung. }\end{array}$ \\
\hline $\begin{array}{c}\text { Treatment } \\
\text { Recommendation } \\
\text { (rekomendasi atas } \\
\text { penanggulangan } \\
\text { masalah) }\end{array}$ & $\begin{array}{c}\text { Detik.com menekankan } \\
\text { penyelesaian masalah } \\
\text { pada perbaikan } \\
\text { komunikasi pemerintah } \\
\text { dari segi koordinasi } \\
\text { mengenai kebijakan } \\
\text { COVID-19 }\end{array}$ & $\begin{array}{c}\text { Kompas.com } \\
\text { menekankan } \\
\text { penyelesaian masalah } \\
\text { pada perbaikan } \\
\text { komunikasi pemerintah } \\
\text { dan lebih serius dalam } \\
\text { menangani pandemi } \\
\text { COVID-19. }\end{array}$ & $\begin{array}{c}\text { Kumparan.com pada berita } \\
\text { memberikan solusi bahwa } \\
\text { juru bicara penanganan } \\
\text { Covid-19 perlu dibantu } \\
\text { oleh Menteri Komunikasi } \\
\text { dan Informasi Johnny G } \\
\text { Plate. }\end{array}$ \\
\hline
\end{tabular}




\section{Framing Entman Dalam Dua Dimensi}

Seleksi isu berkaitan dengan pemilihan fakta dari realitas yang acak dan aspek mana yang ditampilkan. Proses ini selalu ada bagian berita yang dimasukan tetapi ada yang dikeluarkan. Aspek ini berhubungan dengan penulisan fakta yang ditampilkan media ke khalayak.

\section{a. Seleksi Isu dan Aspek Penonjolan di Detik.com \\ - Seleksi Isu}

Ada dua isu yang dimasukan detik.com. Pertama, detik.com menyoroti kebijakan lockdown yang di mana ada kepala daerah melakukan lockdown di daerahnya. Sementara, ada juga daerah yang belum menerapkan lockdown. Terlihat jelas peran pemerintah pusat seolah belum bisa menjawab persoalan kebijakan lockdown. Pada akhirnya, pemerintah daerah mengambil kebijakan masing-masing. Kemudian isu ini dikaitkan dengan pemberian bantuan terhadap masyarakat yang terkena dampak COVID-19. Detik.com berusaha mengingatkan pemerintah agar mengawasi pemberian bantuan sampai ke tangan masyarakat.

Kedua, isu tentang PSBB memperbolehkan masyarakat mudik. Pemerintah mengeluarkan kebijakan PSBB sebagai upaya penekanan virus corona. Namun demikian, pemerintah malah memperbolehkan mudik. Justru hal ini menjadi sumber penularan virus corona karena banyak orang berkerumunan khususnya di transportasi umum. Sehingga isu ini membuat situasi menjadi membingungkan.

Terkait berita komunikasi pemerintah, detik.com mengeluarkan judul berita "Catatan Gerindra Soal Penanganan Corona, Komunikasi Pemerintah Kurang Efektif". Detik.com memilih narasumber Sekjen Gerindra Ahmad Muzani yang memberikan catatan komunikasi pemerintah pusat kurang efektif dalam menangani virus corona. Sebab terdapat perbedaan kebijakan antara pemerintah pusat dengan daerah terkait lockdown, sehingga pemerintah daerah berjalan sendiri tanpa berkoordinasi. Sementara, detik.com menurunkan berita "Pemerintah Bolehkan Mudik di Tengah Corona, Ekonom: Kacau!". Berita ini terlihat jelas di tengah penerapan PSBB yang sedang dijalankan oleh masyarakat, justru pemerintah memperboleh mudik. Hal ini yang membuat situasi menjadi tidak kondusif. Detik.com menggunakan kutipan di berita tersebut Ekonom Senior INDEF Didik Junaedi Rachbini yang menyoroti tidak konsistennya pemerintah dalam mengeluarkan kebijakan.

\section{"Saya nggak ngerti PSBB itu, pemerintah bilang PSBB tapi boleh mudik. Apa pemerintah ngerti? PSBB tapi boleh mudik kan kacau. Pemerintah membolehkan orang berbondong- bondong untuk mudik, di bus-bus itu lah peternakan virus corona nanti," (Paragraf 5 di judul "Pemerintah Bolehkan Mudik di Tengah Corona, Ekonom: Kacau!").}

Sementara, detik.com sebagai cover both side menghadirkan Menteri Koordinator Bidang Kemaritiman dan Investasi yang menjadi Menteri Perhubungan ad interim Luhut Binsar Pandjaitan menanggapi soal komunikasi tidak efektif antar kementerian.

"Kami semua selalu koordinasi dengan baik. Sekarang itu hampir paling tidak tiga kali sehari kami video call dengan presiden, hampir setiap hari dengan topik macam-macam. Jadi koordinasi sangat jelas setelah itu kita telponan," (Paragraf 6 di judul Benarkah Pemerintah Silang Pendapat Tangani Corona? Ini Kata Luhut).

"Jadi kalau ada yang bilang tidak (koordinasi), tidak betul. Misalnya saya dengan pak Basuki kita bicara gimana kalau kita bikin angkutan logistik kita kasih special rate (harga spesial) untuk pengangkutan logistik dalam konteks COVID-19. Sampai itu pun kami 


\section{COVID-19}

bicarakan," (Paragraf 7 di judul Benarkah Pemerintah Silang Pendapat Tangani Corona? Ini Kata Luhut).

Dalam seleksi isu, detik.com menunjukan fakta bahwa isu komunikasi pemerintah menjadi menyangkut hajat orang banyak. Detik.com memasukan isu komunikasi pemerintah dalam rubrik news dan ekonomi. Artinya, isu tersebut tidak hanya aspek nasional saja namun sisi ekonomi perlu diperhatikan.

\section{- Penonjolan Aspek}

Dua hal terkait penonjolan aspek yang ditemukan dalam pemberitaan komunikasi pemerintah di detik.com. Pertama, diksi yang digunakan dalam berita tersebut berkonotasi negatif. Dari tiga berita yang menjadi objek analisis, sebagian besar judulnya menggunakan kata atau kalimat menyudutkan pemerintah. Misalnya, Catatan Gerindra Soal Penanganan Corona, Komunikasi Pemerintah Kurang Efektif dan Pemerintah Bolehkan Mudik di Tengah Corona, Ekonom: Kacau!". Terdapat dua tone yang berbeda namun bermakna konotasi. Di judul pertama "kurang efektif" berarti selama pandemi komunikasi pemerintah bermasalah, indikasi ini merujuk negatif. Judul kedua, monojolkan "kacau!" ditambah tanda seru (!) bisa diartikan berantakan. Penonjolan kata tersebut negative, detik.com ingin memperlihatkan ke publik bahwa kebijakan pemerintah dalam penanganan COVID-19 berantakan. Peneliti juga menemukan bahwa detik.com menggunakan kata dan kalimat yang berkonotasi negatif dalam isi berita. Contoh:

"Saya nggak ngerti PSBB itu, pemerintah bilang PSBB tapi boleh mudik. Apa pemerintah ngerti? PSBB tapi boleh mudik kan kacau. Pemerintah membolehkan orang berbondongbondong untuk mudik, di bus-bus itu lah peternakan virus corona nanti,"

"Sebelum ada PSBB itu sekolah sudah tutup, sebelum ada PSBB orang sudah di rumah saja. Kalau PSBB saja rakyat itu tidak mengerti, harus lebih dirinci. Sentimen negatif dari masyarakat itu dari komunikasi (pemerintah) yang tidak dimengerti. Saya saja nggak mengerti apalagi rakyat," sebutnya.

Kedua, berita detik.com memaparkan hasil survei yang dilakukan oleh Institute for Development of Economics and Finance (INDEF) mengenai kinerja pemerintah dalam menangani virus corona (COVID-19). Berita ini menonjolkan data analyst dari pengguna Twitter yang membicarakan virus corona sebanyak 145.000 orang dan enam portal berita online di Indonesia sejak Januari-Maret 2020. Hasilnya dari 135.000 masyarakat menunjukkan sentimen negatif sebesar 66,28 persen terhadap pemerintah.

\section{b. Seleksi Isu dan Aspek Penonjolan di Kompas.com - Seleksi Isu}

Ada dua isu yang dimasukan kompas.com. Pertama isu tentang pembenahan komunikasi publik dengan penunjukan juru bicara yang handal dan mengerti situasi di tengah pandemi Covid19. Sebab juru bicara tidak sekedar memberi informasi kesehatan kepada khalayak, namun juga membangun kesadaran dan kepecayaan publik serta mampu mengimplementasikan program pemerintah. Karena bencana COVID-19 tidak hanya isu kesehatan tapi berdampak pada sektor lain. Penunjukan juru bicara setiap kementrian dan tingkat daerah sangat diperlukan.

Kedua, isu tentang bentrok kebijakan antarlembaga negara dengan Pemprov DKI Jakarta. Kebijakan yang dikeluarkan pemerintah untuk pencegahan COVID-19 tidak konsisten, tidak transparan dan menimbulkan miskomunikasi antara pemerintahan pusat dan pemerintahan daerah. Misalnya, Kementerian Kesehatan dan Pemprov DKI Jakarta sepakat bahwa melarang ojek online mengangkut penumpang. Sementara, Kementrian Perhubungan mengeluarkan kebijakan yang 


\section{COVID-19}

memperbolehkan ojek online mengangkut penumpang. Justru kebijakan ini membuat publik bingung karena ketidakpastian regulasi.

Terkait berita komunikasi pemerintah, kompas.com mengeluarkan judul berita "Komunikasi Pemerintah soal COVID-19 Dikritik, Jokowi Disarankan Tunjuk Jubir yang Lebih Ulung". Kompas.com memilih narasumber Anggota Komisi III DPR dari Fraksi PPP Arsul Sani yang meminta pemerintah menunjuk Chief of Information Officer (CIO) yang mampu menangani beberapa orang juru bicara. Jika pemerintah tidak serius meng-handle komunikasi publik pemerintah maka kepercayaan masyarakat akan menurun. Sementara, kompas.com menurunkan berita "COVID-19 Bukan Cuma Isu Kesehatan, Pemerintah Diminta Perbaiki Sinergi Informasi". Berita tersebut pada umumnya sama dengan berita sebelumnya, namun terdapat perbedaan yang menyarankan agar setiap kementerian atau lembaga perlu menyiapkan juru bicara.

Selanjutnya, berita tentang bentrok kebijakan pemerintah, ada yang menarik dengan kompas.com menurunkan berita berjudul "Polemik Permenhub soal Ojek Online, PPP Nilai Koordinasi Pemerintah Lemah". Kompas.com menyoroti judul Koordinasi Pemerintah Lemah, hal ini jelas kompas.com menyoroti sekaligus mengkritik kinerja pemerintah yang tidak maksimal dalam konteks komunikasi antar lembaga. Dalam berita tersebut membahas pro dan kontra terhadap pelarang ojek online mengangkut penumpang dan memperbolehkan mengangkut penumpang.

Kompas.com menggunakan pernyataan Sekretaris Fraksi PPP di DPR, Achmad Baidowi yang menyoroti lemahnya koordinasi antar-instansi pemerintah mengenai kebijakan ojek online. Dari sisi pro, Kementerian Kesehatan melarang ojek online untuk mengangkut penumpang kecuali mengangkut barang dan makanan. Peraturan ini berlaku pada Pembatasan Sosial Berskala Besa (PSBB) dalam pasal 15 Peraturan Menteri Kesehatan RI Nomor 9 Tahun 2020. Aturan ini diterbitkan untuk percepatan penanggulangan COVID-19.

"Maka, jika pemotor diperbolehkan mengangkut penumpang tentu tidak memenuhi ketentuan physical distancing," (Paragraf 9 di judul berita Polemik Permenhub soal Ojek Online, PPP Nilai Koordinasi Pemerintah Lemah)

Sementara dari sisi kontra, kompas.com menyoroti Permenhub Nomor 18 Tahun 2020, Pasal 11 ayat 1 huruf c yang melarang sepeda motor mengangkut penumpang. Namun pada huruf d sepeda motor diperbolehkan mengangkut penumpang dengan ketentuan harus memenuhi protokol kesehatan. Hal ini jelas bertentangan dengan Permenkes Nomor 9 Tahun 2020 prinsip PSBB adalah dengan pembatasan jumlah penumpang dengan semangat physical distancing. Perbedaan peraturan tersebut jelas merugikan ojek online yang tidak memiliki kejelasan apakah dibolehkan mengakut penumpang.

"Hal seperti ini seharusnya tidak perlu terjadi. Gara- gara keputusan yang berbeda tersebut, maka para ojek dirugikan. Di satu sisi dilarang, namun di sisi lain diperbolehkan," Paragraf 6 di judul berita Polemik Permenhub soal Ojek Online, PPP Nilai Koordinasi Pemerintah Lemah

Dalam seleksi isu, kompas.com menunjukan fakta isu komunikasi pemerintah sebagai isu nasional. Kompas.com sudah tepat memasukan isu komunikasi pemerintah dalam rubrik nasional bukan isu kesehatan. Apalagi isu komunikasi pemerintah berkaitan dengan kebijakan pemerintah yang mana berkaitan dengan hajat hidup orang banyak. Dengan demikian, pemerintah didesak untuk memperbaiki komunikasi publik, sehingga tidak ada kebingungan di masyarakat. 


\section{- Penonjolan Aspek}

Aspek ini berhubungan dengan penulisan fakta yang ditampilkan media ke khalayak. Adapun dua hal terkait penonjolan aspek yang ditemukan dalam pemberitaan komunikasi pemerintah di kompas.com. Pertama, diksi yang digunakan dalam berita tersebut berkonotasi negatif. Dari empat berita yang menjadi objek analisis, sebagian besar judulnya menggunakan kata atau kalimat mengkritik pemerintah. Misalnya, "Komunikasi Pemerintah soal COVID-19 Dikritik", "Buruknya Komunikasi Pemerintah Tangani COVID-19", "PPP Nilai Koordinasi Pemerintah Lemah" dan "Pemerintah Diminta Perbaiki Sinergi Informasi".

Peneliti juga menemukan bahwa kompas.com menggunakan kata dan kalimat yang berkonotasi negatif dalam isi berita. Contoh:

"Jika presiden tidak membenahi serius komunikasi publik jajaran pemerintahan, maka tingkat kepercayaan masyarakat semakin turun," (Paragraf 6 di judul "Komunikasi Pemerintah soal COVID-19 Dikritik, Jokowi Disarankan Tunjuk Jubiryang Lebih Ulung")

"Untuk Indonesia sendiri, penyebaran telah terjadi karena berbagai hal, salah satunya adalah ketidaksiapan pemerintah sedari awal karena sikap yang terlalu meremehkan ancaman COVID-19," (Paragraf 2 di judul "Koalisi Masyarakat Sipil Soroti Buruknya Komunikasi Pemerintah Tangani COVID-19")

Kedua berita yang disajikan kompas.com cenderung diperkuat dengan data berupa undangundang dari narasumber yang relevan mengenai bentrok kebijakan pemerintah.

Kedua, berita yang disajikan kompas.com cenderung diperkuat dengan data berupa undang-undang dari narasumber yang relevan mengenai bentrok kebijakan pemerintah. Aspek yang ditonjolkan kompas.com bahwa isu komunikasi pemerintah mencakup aspek nasional dan di headline, isi berita, menyelipkan foto-foto korban virus corona dan kegiatan di KRL.

Terdapat dua berita di kompas.com yang menggunakan narasumber berasal dari anggota DPR RI sekaligus politisi PPP untuk menonjolkan kritik terhadap komunikasi pemerintah. Dua narasumber yaitu Arsul Sani dan Achmad Baidowi yang keduanya merupakan partai koalisi pemerintah. Dua narasumber ini biasanya tampil membahas mengenai politik dalam negeri dan membela kebijakan pemerintah. Berikut kutipan kedua narasumber tersebut mengkritik komunikasi pemerintah:

"Jika presiden tidak membenahi serius komunikasi publik jajaran pemerintahan, maka tingkat kepercayaan masyarakat semakin turun," kata Arsul. (Paragraf 7 pada judul "Komunikasi Pemerintah soal COVID-19 Dikritik, Jokowi Disarankan Tunjuk Jubir yang Lebih Ulung")

"Hal ini menunjukkan lemahnya aspek komunikasi dan koordinasi antar-instansi di pemerintahan dalam penerapan PSBB, sehingga menghasilkan kebijakan berbeda," kata Baidowi. (Paragraf 4 di judul "Polemik Permenhub soal Ojek Online, PPP Nilai Koordinasi Pemerintah Lemah")

\section{c. Seleksi Isu dan Aspek Penonjolan di Kumparan.com}

\section{- Seleksi Isu}

Ada tiga isu yang dimasukan kumparan.com. Pertama, isu yang dibahas komunikasi pemerintah buruk terkait pernyataan Juru Bicara Presiden Fadjroel Rachman yang diralat oleh Menteri Sekretariat Negara Praktikno soal kebijakan mudik. Kumparan.com menyoroti juru bicara 


\section{COVID-19}

presiden tidak ada garis koordinasi yang jelas. Akibatnya, pemerintah menghadapi kesulitan memberikan informasi terkait COVID-19.

Kedua, isu tentang perbaikan komunikasi pemerintah dari segi pembahasan. Sebab, selama ini informasi yang dipublikasikan ke khalayak hanya sekedar update jumlah positif virus corona. Menteri Komunikasi dan Informatika Johnny G Plate memiliki peran penting menyampaikan pesan positif dengan menyelipkan program pemerintah terkait pandemi. Ketiga, kumparan.com ingin menunjukan pembaca bahwa kebijakan ojek online terdapat masalah peraturan yang dibuat 2 kementerian. Sehingga kebijakan tersebut membuat publik bingung.

Terkait berita komunikasi pemerintah, kumparan.com mengeluarkan tiga judul yang cenderung mengkritik pemerintah. Judul pertama "Politikus PKS Kritik Istana yang Tak Satu Suara Soal Staf KSP Positif Corona”, kumparan.com memilih narasumber Ketua DPP PKS sekaligus Anggota DPR RI Mardani Ali Sera menilai koordinasi di lingkar istana negara masih lemah dan tidak jelas garis komando terkait penanganan COVID-19. Judul berita kedua, "Komisi 1 DPR Komentari Jubir Penanganan COVID-19: Jangan Hanya Jumlah Korban", Anggota Komisi I DPR RI dari Fraksi Partai Demokrat, Syarief Hasan mengkritik juru bicara Gugus tugas percepatan penanganan COVID-19, Achmad Yurianto yang setiap harinya memberi informasi jumlah kasus positif corona. Judul berita ketiga. "Komisi III Kritik Koordinasi Luhut-Terawan soal Ojol: Warga Bisa Tak Ikuti PSBB", kumparan.com memilih narasumber Anggota Komisi III DPR dari Fraksi PAN Sarifuddin Sudding menyesalkan peraturan kementerian kesehatan dan kementerian perhubungan saling bertentangan.

Dalam seleksi isu, kumparan.com menunjukan fakta isu komunikasi pemerintah sebagai isu krusial karena isi tiga berita tersebut mengkritik membangun agar pemerintah dapat dengan baik menangani COVID-19 dengan baik. Apalagi kondisi pandemi dibutuhkan komunikasi terukur, terarah, proposional dan tepat, sehingga tidak ada lagi kebijakan yang membingungkan publik.

\section{- Penonjolan Aspek}

Aspek ini berhubungan dengan penulisan fakta yang ditampilkan media ke khalayak. Adapun dua hal terkait penonjolan aspek yang ditemukan adalah diksi yang digunakan dalam berita tersebut cenderung menyudutkan pemerintah. Dari ketiga berita tersebut isi beritanya memaparkan kesalahan pemerintah. Berikut kata atau kalimat berkonotasi negatif yang ditonjolkan kumparan.com:

- $\quad$ Pemerintah menunjukkan komunikasi publik yang buruk

- $\quad$ Antisipasi pemerintah yang buruk

- Ketidak-jelasan garis komando

- Pemerintah terlambat hadir

- Masyarakatlah yang kebingungan

- $\quad$ Pemerintah memberikan contoh yang tidak baik

Berita yang disajikan kumparan.com menonjolkan bahwa isu komunikasi pemerintah tidak hanya mencakup kesehatan, tetapi aspek politik terlihat di headline, isi berita dan menampilkan foto ojek online. Berita kumparan.com dominan menggunakan narasumber di luar koalisi partai politik pemerintah seperti Mardani Ali Sera dan Sukamta dari PKS, Syarief Hasan dari Partai Demokrat dan Sarifuddin Sudding dari PAN. Hanya Menteri Komunikasi dan Informatika Johnny G Plate sebagai perwakilan pemerintah. 


\section{KESIMPULAN}

Berdasarkan analisis framing dari ketiga media online detik.com, kompas.com dan kumparan.com ditemukan adanya perbedaan dalam penyajian berita komunikasi pemerintah di COVID-19. Detik.com membingkai komunikasi pemerintah sebagai permasalahan serius yang harus ditanggapi secara tanggap, cepat dan proposional. Kemudian, kompas.com membingkai komunikasi pemerintah sebagai isu krusial maka frame kompas.com, cenderung mengkritik membangun. Sedangkan, kumparan.com membingkai isu komunikasi pemerintah dari aspek politik dengan menyebut koordinasi antar pemerintah lemah.

Seleksi isu detik.com, lebih kepada permasalahan yang berdampak langsung terhadap masyarakat. Detik.com menitik beratkan kepada kebijakan pemerintah yang tidak konsisten, sehingga masyarakat menjadi bingung seperti kebijakan lockdown dan mudik. Detik.com cenderung menonjolkan diksi berkonotasi dan narasumber yang dipilih mengkritisi komunikasi pemerintah.

Seleksi isu kompas.com lebih kepada permasalahan komunikasi pemerintah. Pertama, pemerintah diminta untuk memperbaiki juru bicara yang mampu membangun kepercayaan publik. Kedua, lemahnya koordinasi antar kementerian. Ketiga, ketidaksiapan pemerintah dan terkesan meremehkan COVID-19. Kompas.com lebih menonjolkan kritikan membangun yang menunjukan bahwa komunikasi pemerintah harus diperbaiki khususnya penyampaian informasi ke publik terkait kebijakan COVID-19.

Seleksi isu kumparan.com lebih kepada permasalahan juru bicara presiden dan juru bicara gugus tugas percepatan penanganan COVID-19. Kumparan.com menonjolkan diksi dalam berita (headline dan isi berita) cenderung menyudutkan pemerintah.

\section{DAFTAR PUSTAKA}

Alexa. 2020. Top Sites in Indonesia. https://www.alexa.com/topsites/countries/ID. (Diakses pada 23 Juli 2020).

Denzin, K. Norman \& Lincoln, Yvonna S. 2009. Handbook Of Qualitative Researsch. Yogyakarta: Pustaka Pelajar.

Eriyanto 2012. Analisis Framing: Konstruksi, Ideologi, dan Politik Media. Yogyakarta: PT. LKIS Pelangi Aksara.

-. 2013. Analisis Isi: Pengantar Metodologi untuk Penelitian Ilmu Komunikasi. Jakarta: Prenada Media

Iskandar, Dudi Sabil dan Lestari, Lestari. 2016. Mitos Jurnalisme. Yogyakarta: ANDI.

Jusuf Kalla School of Gobernment. 2020. Research Press Release: Framing Media Terhadap Kepercayaan Publik dalam Kebijakan Pandemi COVID19 di Indonesia. https://jksg.umy.ac.id/research-press-release-framing-media-terhadap-kepercayaanpublik-dalam-kebijakan-pandemi-covid19-di-indonesia/. (Diakses pada 26 Juli 2020).

Kompas.com. 2020. Koalisi Masyarakat Sipil Soroti Buruknya Komunikasi Pemerintah Tangani Covid-19. https://megapolitan.kompas.com/read/2020/04/13/17453901/koalisimasyarakat-sipil-soroti-buruknya-komunikasi-pemerintah-tangani (Diakses pada 11 Mei 2020). 


\section{BINGKAI MEDIA TERHADAP BERITA KOMUNIKASI PEMERINTAH DI PANDEMI}

\section{COVID-19}

Republika. 2020. Komunikasi Wabah Corona. https://republika.co.id/berita/q7mrdi469/komunikasi-wabah-corona. (Diakses pada $11 \mathrm{Mei}$ 2020).

Syam, Hamdani M. 2016. Jurnalisme Damai Memahami Sistem Pemberitaan Di Daerah Konflik. Yogyakarta: Samudra Biru.

Suryawati, Indah. 2019. Strategi Ketahanan Pangan Indonesia dalam Konstruksi Media (Analisis Framing Pada Berita Tirto.Id). Jurnal Komunikatif Vol 8, No 1 (2019)

Susanto, Eko Harry. 2011. Dinamika Media Massa Lokal dalam Membangun Demokratisasi di Daerah. Jurnal Ilmu Komunikasi, Volume 9, Nomor 2, Mei-Agustus 2011, halaman 117127

Voaindonesia. 2020. Pemerintah Harus Perbaiki Komunikasi Publik Terkait Corona. https://www.voaindonesia.com/a/pemerintah-harus-perbaiki-komunikasi-publik-terkaitcorona/5364324.html. (Diakses pada 25 Mei 2020). 